GENDER STUDIES 20(1)/2021

\title{
sciendo
}

\subsection{8/genst-2022-0004}

\section{SPEAKING WITH THE DEAD: THE SICK CHICK AND \\ THE PSYCHIC CRYPT IN GAIL HONEYMAN'S \\ ELEANOR OLIPHANT IS COMPLETELY FINE}

\author{
CATHERINE MACMILLAN \\ Yeditepe University, Istanbul \\ cathymacmillan@hotmail.co.uk
}

\begin{abstract}
This paper explores Gail Honeyman's 2017 novel Eleanor Oliphant is Completely Fine from the perspective of Abraham and Torok's concept of the psychic crypt. On one level the protagonist Eleanor, a thirty-year-old urban single woman searching for love, resembles a chick-lit heroine; however, Eleanor is deeply lonely, apparently autistic, suicidal and a survivor of childhood abuse and trauma. The paper argues that Eleanor's difficulties can be understood as the consequences of encryptment which, in Abraham and Torok's terms, is a disease of mourning where the dead loved one is incorporated rather than introjected into the psyche.
\end{abstract}

Keywords: crypt, introjection, loneliness.

\section{Introduction}

It is arguably difficult to classify Gail Honeyman's 2017 bestselling and critically acclaimed novel Eleanor Oliphant is Completely Fine according to genre. On one level, the novel does appear to include all of the main attributes of chick-lit, a genre whose origin is frequently traced back to the 1996 publication of Helen Fielding's Bridget Jones's Diary (Montoro, 2012, p. 5). Usually narrated by the protagonist in a confessional style, chick-lit novels are "written by women, (largely) for women, depicting the life, loves, trials and tribulations of their predominantly young, single, urban, female protagonists" (Gormley, 2009). These protagonists are usually "flawed" young women (Montoro, 2012, p. 6) who are "seeking fulfillment in a romance-consumer-comedic vein" (Knowles, 2004, p. 2).

Indeed, typically of chick-lit, Eleanor Oliphant is a young, single woman approaching her thirtieth birthday and looking for love. Like many chick-lit protagonists, she is an urban career woman, although she lives in Glasgow rather than in a glitzy area of New York or 
London, and her office job is not a glamourous one. Moreover, the novel is peppered with the shopping and makeover scenes characteristic of chick-lit, and which chronicle Eleanor's attempt to become, as she puts it, "shiny." Finally, typical for a chick-lit novel, Eleanor herself narrates her story in a confessional tone; her narration is frequently humourous, albeit, as is discussed further below, usually unintentionally so.

However, despite these similarities, Eleanor Oliphant is Completely Fine is certainly not a typical chick-lit novel, and Eleanor herself is far from being a typical chick-lit protagonist. It quickly becomes clear that Eleanor is, in fact, definitely not "completely fine," and that her problems go way beyond those of the "singleton" protagonists (Montoro, 2012, p.5) of most examples of "cappucino fiction" (Montoro, 2012, p.1). Indeed, although she narrates her story with a disarming absence of self-pity, it quickly becomes clear that Eleanor's life is a terribly isolated and lonely one, so much so that she even questions her own existence:

\footnotetext{
No one's been in my flat this year apart from service professionals; I've not voluntarily invited another human being across the threshold, except to read the meter. You'd think that would be impossible, wouldn't you? It's true though. I do exist, don't I? It often feels as if I'm not here, that I'm a figment of my own imagination. There are days when I feel so lightly connected to the earth that the threads that tether me to the planet are gossamer thin, spun sugar. (Honeyman, 2017, p. 5)
}

Despite being highly intelligent - she was an outstanding student of Classics, and had "won a small prize for the best Finals performance in a paper on Virgil's Georgics" (Honeyman, p. 2017, p. 50) - Eleanor clearly suffers from social difficulties. Notably, she is extremely uncomfortable in situations where she has to make small talk, and does not comprehend its social function:

I try to plan my exits from the office so that I don't need to talk to anyone on the way out. There are always so many questions. What are you up to tonight? Plans for the weekend? Booked a holiday yet? I've no idea why other people are so interested in my schedule. (Honeyman, 2017, p. 42)

Eleanor's social isolation is exacerbated by the fact that her strange behaviour tends to unsettle her interlocutors, ironically leading her to perceive them as socially inept: she bemoans that, "[i]n every walk of life I encounter people with underdeveloped social skills with alarming frequency" (Honeyman, 2017, p. 49).

In this context, Eleanor's search for love is an unorthodox one: emotionally immature despite her intellectual gifts, Eleanor develops an obsession with Johnnie Lomond, a handsome 


\section{GENDER STUDIES 20(1)/2021}

singer whom she has never met, a crush which seems more appropriate for a girl of thirteen than a woman of thirty. However, it is Eleanor's co-worker, the scruffy, down-to-earth, kindly Raymond Gibbons who provides the real love in Eleanor's life by treating her with warmth and friendship, encouraging her to open up to the world and even saving her life following her suicide attempt.

Although her behaviour may at first encourage the reader to believe that Eleanor is on the autism spectrum, as the story unfolds, it gradually becomes clear that her social difficulties are a result of childhood trauma: as Honeyman herself points out, she is "the product of nurture, not nature" (Woods, 2018). The physical effects of Eleanor's childhood trauma become evident early in the novel; Eleanor mentions smoke damage to her voice and a scar on her face, the after-effects of a fire. As Eleanor notes, "[e]ven the circus freak side of my face - my damaged half - was better than the alternative, which would have meant death by fire" (Honeyman, 2017, p.85).

Moreover, the reader discovers that, at the age of 11, Eleanor was placed in foster care, with the Reed family, presumably due to her mother's imprisonment. Eleanor identifies with Jane Eyre, also unhappily fostered by a Reed family; Jane, like Eleanor herself, was “[a] strange child, difficult to love. A lonely, only child. She's left to deal with so much pain at such a young age - the aftermath of death, the absence of love" (Honeyman, 2017, p. 82). Due to her "problematic" behaviour, however, Eleanor, like Jane, is soon sent away, in Eleanor's case to an orphanage (Honeyman, 2017, pp. 60-62).

Nevertheless, the full nature of her trauma is fully revealed, both to the reader and to Eleanor herself, only when she undergoes therapy following a suicide attempt. Thus, it is only late in the novel that Eleanor recovers her memory of the traumatic event; when she was ten years old, her mother attempted to murder her and her little sister Marianne by setting their house on fire. While, despite her physical and psychological scars, Eleanor survived, her fouryear-old sister was killed. The most surprising secret of all, however, is revealed only at the very end of the novel: it turns out that Eleanor's mother, with whom Eleanor has weekly telephone conversations, had also died in the fire twenty years before. As Santos Brigida notes, this surprise dénoument "might come out to some as a slightly inferior demonstration of the author's fiction-making ability when compared to the rest of the novel" (2018, p. 5). However, as is explored further below, it is argued that the concept of the psychic crypt, developed by psychologists Nicolas Abraham and Maria Torok, may help to shed light on Eleanor's difficulties, including her conversations with her dead mother. 


\section{GENDER STUDIES 20(1)/2021}

\section{A “Mummy"fied past: Eleanor Oliphant's psychic crypt}

\subsection{Abraham and Torok and the psychic crypt}

As Rashkin notes, Abraham and Torok's (1992) work can provide a valuable perspective for literary studies, particularly for studying characters who, like Eleanor, "can be understood to be propelled by the haunting presence of a secret beyond his or her awareness" (p. 44). Notably, Abraham and Torok's theory, as explored further below, is concerned with the effects of trauma, and:

with how certain events or dramas could be experienced as so psychically disruptive that any attempt to absorb or integrate them within the ego would destabilise it and block if not destroy the subject's ability to be. (Rashkin, 2008, p. 15)

However, for Abraham and Torok trauma is subjective rather than objective in nature; it is thus not "the content per se of an event but the fact that an individual lived intrapsychically as shameful, humiliating and potentially annihilating" that renders it traumatic (Rashkin, 2008, p. 15). In Abraham and Torok's view, such traumas, specifically those resulting from an unconscious refusal or inability to mourn a deceased love object, may result in the formation of a psychic crypt, an isolated wound in the psyche comparable to "the formation of a cocoon around the chrysalis" (Abraham and Torok, 1987, p. 141). The crypt then acts as a "sort of artificial Unconscious, lodged at the very heart of the Ego" (Abraham and Torok, 1987, pp. 254-255) where the subject's memories of the dead loved one are "buried alive ... as a fullfledged person" (Abraham and Torok, 1987, p. 130). In this sense, then, "the incorporated phantom dwelling in the crypt," in this case Eleanor's mother, "would come to haunt and obsess the traumatised, suffering subject transformed into a phantom-bearer or cryptophore" (Ganteau, 2013, p. 21).

As Abraham and Torok (1987) put forward, a psychic crypt is formed to "house" the departed loved one in the subject's psyche in secret. Crypts occur when, although they are overcome by grief, the survivor is deluded into believing that no trauma or loss has occurred (p. 104); they are formed in cases where "the abrupt loss of a narcissistically indispensable object of love has occurred, yet the loss is of a type that prohibits its being communicated" (p. 129).

The roots of Abraham and Torok's concept of the psychic crypt can perhaps be found in Freud's essay Mourning and Melancholia, in which he attempts to distinguish between 


\section{GENDER STUDIES 20(1)/2021}

"normal" mourning and melancholia: normal mourning gradually dissipates, whereas melancholia "circles around itself, exhausting its victim, sometimes to the point of selfannihilation" (Sprengnether, 2018, p. 193). For Freud, melancholia may result from ambivalent feelings of love and hate towards the lost object. In this context, the melancholic person, instead of retracting the libido invested with the lost object and redirecting it to another object, directs it inwards: "the ego wants to incorporate this object into itself" (Freud, 1991, p. 258). As a result, part of the subject identifies with the lost person, resulting in an inner split; the melancholic's violent self-reproaches are, in effect, reproaches against the lost object (Freud, 1991, pp. 251-268).

In this context, Abraham and Torok draw on Ferenczi's concept of introjection, which is characteristic of "normal" mourning, and which can be described as "the extension of autoerotic interests, the broadening of the ego through the removal of repression, and ... an extension to the external world of the original autoerotic interests" (Abraham and Torok, 1987, pp. 110-113). However, Abraham and Torok argue that the crypt is formed by incorporation rather than introjection, which occurs when loss is denied, generating a "melancholic fantasy of absorbing the lost other into the self" (Abraham and Torok, 1987, pp. 127-130). As Derrida notes, "[s]ealing the loss of the object but also marking the refusal to mourn, such a manouver is foreign to and actually opposed to the process of introjection" (Derrida, 1986, p. xvi); this incorporation is "fantasmatic, unmediated, instantaneous, magical, sometimes hallucinatory" (Derrida, 1986, p. xvii).

The crypt is, then, "a commemorative monument", "the vault of a desire"; however, it does not commemorate the object itself but rather "its exclusion, the exclusion of a specific desire from the introjection process" (Derrida, 1986, p. xvii). In this context, "[s]ecrecy is essential, whence the crypt, a hidden place, a disguise hiding the traces of the act of disguising, a place of silence" (Derrida, 1986, p. xvii). The ego unconsciously assumes the role of guardian of this crypt, from which "nothing should filter out to the external world" (Abraham and Torok, 1987, pp. 254-255). However, sometimes "in the dead of night ... the ghost of the crypt comes back to haunt the cemetery guard, giving him strange and incomprehensible signals, making him perform bizarre acts, or subjecting him to unexpected sensations" (Abraham and Torok, 1987, p. 130). Thus, the trauma that provoked the encryptment in the first place is repeated rather than resolved:

The crypt is always an internalization, an inclusion intended as a compromise, but since it is a parasitic inclusion, an inside heterogenous to the inside of the Self, an outcast in the domain of general introjection 
GENDER STUDIES 20(1)/2021

within which it violently takes its place, the cryptic safe can only maintain in a state of repetition the mortal conflict it is impotent to resolve. (Derrida, 1986, p. xvi)

\section{2 (De)encrypting 'Mummy': Eleanor's entombed secret and the long road to recovery}

The concept of the psychic crypt, as discussed above, can arguably shed further light on Eleanor Oliphant's telephone conversations with her dead mother, as well as on her loneliness, social difficulties and depression. As has already been touched on, Eleanor's problems have their root in childhood trauma, specifically in her mother's attempt to murder Eleanor and her sister by setting fire to their house while they were tranquilised and sleeping. While Eleanor's experience can be considered traumatic by any standard, the subjective perception of trauma, as has already been noted, is important from Abraham and Torok's perspective. The crypt has its origins in such traumatic events, and "is built by violence" (Derrida, 1986, p. xv). More specifically, as has already been noted, encryptment results from a refusal to mourn, to introject, the dead person as the consequence of a shared and unspeakable secret, so that:

I pretend to keep the dead alive, intact, safe (save) inside me, but it is only in order to refuse, in a necessarily equivocal way, to love the dead as a living part of me, dead save in me, through the process of introjection as happens in so-called normal mourning. (Derrida, 1986, pp. xvi-xvii)

In such cases, "the 'shadow of the object' strays endlessly about the psychic crypt until it is reincarnated in the person of the subject", while "the 'object' in its turn, carries the ego as a mask, that is, either the ego itself or some other façade" (Abraham and Torok, 1987, p. 141). Thus, the crypt can be understood as a kind of "false unconscious ... lodged in a prothesis, a graft in the heart of an organ, within the divided self" (Derrida, 1986, p. xii). In this context, as Abraham and Torok (1987) argue, the mechanism of the crypt:

consists of exchanging one's own identity for a fantasmic identification with the "life" - beyond the grave - of an object of love, lost as a result of some metapsychological traumatism. Lacking a better term, we will call this process endocryptic identification. (p. 142)

The refusal to mourn, which provokes this encryptment, arises from an unspeakable secret which was shared between the subject and the dead object: "No crypt arises without a shared secret's having already split the subject's topography" (Abraham and Torok, 1987, p. 


\section{GENDER STUDIES 20(1)/2021}

131). Importantly, moreover, the object, in Eleanor's case, her mother, rather than the subject is the source of the terrible secret:

Crypts are constructed only when the shameful secret is the love object's doing and when that object also functions for the subject as an ego ideal. It is therefore the object's secret that needs to be kept, his shame covered up. (Abraham and Torok, 1987, p. 131)

While the adult Eleanor cannot, at least consciously, remember the details of her mother's crime, her "telephone" relationship with her encrypted mother reveals a relationship which is strained to say the least. Notably, it is always the mother who contacts Eleanor; Eleanor herself always appears loath to talk to her, although, as she explains, "however much I might wish it were otherwise, she always managed to get through to me in the end" (Honeyman, 2017, p. 33).

Indeed, Eleanor's reluctance is not surprising, as her mother appears to be emotionally abusive, constantly belittling Eleanor, attempting to destroy whatever self-confidence she has been able to muster, and often reducing her to tears. The following extract is illustrative:

Don't you go getting sidetracked now, Eleanor- don't go ignoring Mummy, will you? Oh you think you're so smart now, don't you, with your job and your new friends. But you're not smart, Eleanor. You're someone who lets people down. Someone who can't be trusted. Someone who failed. Oh yes, I know exactly what you are. And I know how you'll end up. Listen, the past isn't over. The past is a living thing. Those lovely scars of yours - they're from the past, aren't they? And yet they still live on your plain little face. (Honeyman, 2017, p. 132)

Despite her mother's constant emotional abuse, she does seem to act as an ego ideal for Eleanor which, as Abraham and Torok emphasise, is a prerequisite for encryptment (1987, p. 131). Thus, Eleanor constantly tries, and fails, to please her mother, so that even her disastrous attempt to seduce Johnnie Lomond is motivated by an attempt to placate "Mummy:"

There he was, a gift from the gods - handsome, elegant and talented. I was fine, perfectly fine on my own, but I needed to keep Mummy happy, keep her calm so that she would leave me in peace. A boyfriend - a husband? - might just do the trick. It wasn't that I needed anyone. (Honeyman, 2017, p. 27)

Moreover, in spite of herself, Eleanor has at least partly internalised her mother's exacting and arguably rather snobbish "standards" in everything from her taste in men, to food and interior decorating. 
Eleanor's identification with her mother may, on the face of it, appear rather puzzling particularly because, as is discussed further below, she routinely physically and psychologically abused Eleanor and her little sister Marianne as children. However, Ferenczi's concept of identification with the aggressor may shed further light on Eleanor's situation here. According to Ferenczi (1995), in an attempt to survive in extreme circumstances, the traumatised child "adapts itself to its difficult task with the aid of complete identification with the aggressor" (p. 190). In this context, the child's own agency is effectively lost and replaced with that of the perpetrator, while the child also becomes hypersensitive to the perpetrator (Frankel, 2002); as Rashkin notes, however, the child identifies not so much with the aggressor but rather with "an image of itself created by the adult" (2008, p. 164).

Identification with the aggressor can, then, be understood as a social strategy to "forestall lack of control, fear and the like". However, it also provokes intrapsychic change in the form of a splitting of the ego (Bonomi, 2002, p. 153). As Leys (2000) notes, the "traumaticmimesis" does not encompass the entire ego, leaving a "resisting, self-observing, spectatorial fragment" in place (p. 134). This intrapsychic change is, therefore, perhaps reminiscent of the effects of the crypt, in that it takes the form of "dissociation/fragmentation of the personality, sequestring of the trauma, emotional abandonment and isolation" (Bonomi, 2002, p.153).

As Abraham and Torok argue, then, for encryptment to take place, there must be a previous experience related with the object which results in a splitting of the ego: "Every time an incorporation is uncovered, it can be attributed to the undisclosable grief that befits an ego already partitioned on account of a previous objectal experience tainted with shame" (1987, p. 131). In Eleanor's case, this is arguably explained by the physical and psychological abuse that she, along with her little sister Marianne, received from their mother even before the fateful arson attack. As Eleanor later remembers:

School had been a place of refuge. Teachers asked how you got your cuts and bruises, sent you to the nurse to have them dressed... It wasn't long after the picnic that Mummy found out Mrs Rose had been asking about my bruises. We were home-schooled after that, all day every day - no more escaping from nine to four, Monday to Friday. Worse and worse, quicker and quicker, hotter and hotter, fire. (Honeyman, 2017, p. 340)

Eleanor's recovery, her own psychological recovery as well as the recovery of her buried memory, appears to begin as a result of her visits to a therapist, Maria Temple, following her suicide attempt, ostensibly a result of her failed (non)relationship with the singer. Sensing deeper problems, however, Eleanor's therapist encourages her to express her feelings towards 
her mother, who is represented by a chair; the exercise leaves Eleanor weeping, and begging "Mummy ... please.... Please don't hurt us" (Honeyman, 2017, p. 294).

Another important component of Eleanor's trauma that is gradually revealed is her repressed feelings of guilt towards her sister Marianne, who perished in the fire. Indeed, while the adult Eleanor appears to have, at least at a conscious level, forgotten about Marianne's existence, her memory of her sister is gradually recovered during the therapy sessions. Thus, along with her mother, Eleanor also appears to have encrypted Marianne; as Derrida (1986) notes:

the crypt must always incorporate more than one and behave towards it in more than one way. More than one: the secret must be shared, at least with a "third"; that is what makes the secret a secret. (pp. xviiixix)

In contrast to "Mummy", however, Marianne's ghostly presence is quiet, barely perceptible: "Something - someone - was niggling at me, though, tugging at my sleeve. I tried to ignore her but she wouldn't go away, that little voice, those little hands" (Honeyman, 2017, p. 309). At first, Eleanor even apparently confuses her with a dog: "Pale brown eyes. Something about a dog. But I've never had a pet" (Honeyman, 2017, p. 309). Thus, Marianne, as the incorporated third party, is "held in so as to be crossed out, kept alive so as to be left for dead, enveloped by the scene" (Derrida, 1986, p. xix).

The recovery of Eleanor's memory of Marianne is accompanied by the return of her feelings of guilt and powerlessness. Eleanor blames herself for provoking her mother to start the fire which killed Marianne (Honeyman, 2017, p. 340); she also feels guilty at not having been able to rescue her from the burning house, and for surviving at all when her sister perished. As Eleanor tells her therapist:

It's the guilt though ...I was her big sister, I should have been looking out for her. She was so small. I did try, I really did, but it just ... it wasn't enough. I failed her, Maria, I'm still here and that's all wrong. It should be her who survived. I don't deserve to be happy, I don't deserve to have a nice life when Marianne ... (Honeyman 2017: 353)

Notably, Elinor and Marianne are also the names of the sisters in Jane Austen's Sense and Sensibility, where Elinor represents sense, i.e. reason and judgement, and Marianne sensibility, or feeling and emotion. Thus, this intertextual reference perhaps highlights that, with the loss of Marianne, Eleanor Oliphant also lost touch with her own emotional side, which had, prior to 


\section{GENDER STUDIES 20(1)/2021}

her sister's death, been evident in her love for Marianne. This is illustrated, for instance, when Maria asks Eleanor whether her emotional needs were satisfied during her childhood in care. Eleanor is confused by the question, replying: "But I don't have any emotional needs" (Honeyman, 2017, p. 308).

Although Eleanor has not yet fully uncovered the secret she shares with her encrypted mother, her mother already seems to be showing signs of weakness during her next call to Eleanor; she has developed a hacking cough, for instance, and complains that "I'm starting to fall apart!" (Honeyman, 2017, p. 300). Most notably, however, Eleanor gets the impression that her mother is afraid: "As always, Mummy was scary. But the thing was, this time - for the first time ever - she's actually sounded scared too" (Honeyman, 2017, p. 302). In fact, Eleanor's mother, perhaps sensing her imminent demise, begins to threaten Eleanor about the consequences of revealing their shared secret, although, as if she is already losing her power over her daughter, she is unable to completely verbalise the threat:

Under no circumstances are you to discuss your childhood with anyone, especially not a so-called 'counsellor'. Do you hear me? Don't you dare. I'm warning you, Eleanor. If you start down that path, do you know what will happen? Do you know what I'll do? I'll-' (Honeyman, 2017, p. 302)

This threat is notably reminiscent of that attributed to Gilles, the encrypted elder brother of Abraham and Torok's patient Victor, with reference to an "unspeakable scene" that had been shared between the boys: "I'll bash you on the head if you tell anyone what we did together" (Abraham and Torok, 1987, p. 143).

In her final conversation with her mother, Eleanor, having recuperated her memory of the events thanks to her therapy sessions, confronts her encrypted mother with her crime: "You set fire to the house while Marianne and I were asleep inside. She died in there". Her mother callously replies, "If something needs to change, change it! Of course, there will be inconveniences along the way ... you simply have to deal with them, and not worry too much about the consequences" (Honeyman, 2017, p. 374).

The realisation that her mother viewed her and her sister merely as inconveniences to be got rid of finally enables Eleanor to cut her ties with her encrypted mother, allowing her to begin to recuperate her own identity. "And, underneath it all, like an embryo forming - tiny, so tiny, barely a cluster of cells, the heartbeat as small as the head of a pin, there I was. Eleanor Oliphant." (Honeyman, 2017, p. 374) 


\section{GENDER STUDIES 20(1)/2021}

By the end of the novel, Eleanor appears to be well on the way to being "completely fine." However, she realises that, despite the progress she has made, her recovery will be long and arduous, as she tells Raymond:

I'm fine, I mean, yes, obviously, I've got a lot of things to work through, very serious things. Dr Temple and I are going to keep talking about all of it - Marianne's death, how Mummy died too, and why I pretended for all those years that she was still there, still talking to me ... it's going to take time and it's not going to be easy. (Honeyman, 2017, p. 381)

Indeed, as Abraham and Torok argue, treatment of a psychic crypt is a lengthy and risky process which proceeds in stages, and which requires very specific and careful treatment on the part of the analyst (Abraham and Torok, 1987, pp. 155-156). Careless or mistaken analysis, in this context, can even lead to suicide (Abraham and Torok, 1987, pp. 137-138).

In addition to her therapy sessions, and her friendship with Raymond, who provides her with love and support following her suicide attempt and during her recovery, hope arrives for Eleanor in the plump and perhaps unlikely shape of Glen, a black cat with large bald patches who was rescued from a burning dustbin. The helplessness of the affectionate cat, given to her by Raymond, inspires tenderness and a sense of responsibility in Eleanor, keeping her away from alcohol even when she desperately craves it following her difficult therapy sessions. In this way by taking care of a small, vulnerable creature, Eleanor can perhaps assuage her guilt over her inability to save Marianne, who was, after all, another small, vulnerable creature.

Moreover, Glen can arguably be read as a symbol of Eleanor's trauma and of her hope of recovery. Despite belonging to different species, Glen and Eleanor share much in common: like Eleanor, Glen is a survivor of arson, she is physically disfigured by her alopecia and is not particularly sociable. However, Glen, is a happy and well-adjusted cat despite her difficulties, indicating that perhaps Eleanor too may one day overcome her traumatic past to be well, truly and completely fine.

\section{Conclusion}




\section{GENDER STUDIES 20(1)/2021}

Although it perhaps superficially resembles a chick-lit novel, Eleanor Oliphant is Completely Fine deals with some far darker themes than is typical for the genre. Reading the novel through the lens of Abraham and Torok's theory of the psychic crypt, this paper has attempted to provide a new insight into Eleanor's isolation and social difficulties. A reading from the perspective of the psychic crypt also helps to make sense of the fact that Eleanor's mother, with whom she has long had weekly telephone conversations, is long dead.

Abraham and Torok's concept of the psychic crypt can be described as a disease of mourning according to which, due to an inability to mourn the dead love object, the dead object is introjected rather than incorporated into the psyche. This results in the dead object being, as it were, "buried alive" in the subject's ego. While the encrypted object remains secret, even or perhaps especially to the subject themselves, it perpetuates psychological disturbances and distress in the sufferer, as can be seen in the case of Eleanor. For Abraham and Torok, several conditions have to be fulfilled for encryptment to take place. Firstly, the encrypted love-object must have constituted an ego-ideal for the subject. Despite the terrible physical and psychological abuse that she suffered at the hands of her mother, Eleanor continues, in vain, to try to live up to her encrypted mother's expectations of her, and has internalised her mother's rather snobbish outlook on life. Secondly, encryptment can only take place in a psyche which is already split by an earlier, unspeakable secret shared by the subject and the departed love object. In Eleanor's case, this secret is arguably the abuse that Eleanor's mother inflicted both on the young Eleanor and her little sister Marianne, in the period leading up to the fatal arson attack.

More generally, this reading of Eleanor Oliphant is Completely Fine from the perspective of the psychic crypt appears to support Rashkin's argument regarding the relevance of Abraham and Torok's work for literary analysis, particularly in the case of literary works which, like Eleanor Oliphant, deal with the psychological effects of trauma and family secrets. In contrast to the stories analysed by Rashkin, however, the unspeakable secret in Eleanor Oliphant is not left to be deciphered entirely by the reader; instead it is gradually revealed, both to the reader and to Eleanor herself, as Eleanor begins to recover from the effects of her traumatic childhood. Eleanor's recovery is aided not only by the emotional support of her friend Raymond, who actually saves her life after her suicidal drinking binge, but also by her sessions with her therapist, Maria Temple. It is these sessions which enable Eleanor to face the events of her past and, gradually, to face and to incorporate her encrypted mother, allowing Eleanor's own identity to begin to shine through.

\section{References}




\section{GENDER STUDIES 20(1)/2021}

Abraham, N. and M. Török (1987). The Shell and the Kernel: Renewals of Psychoanalysis. University of Chicago Press.

Bonomi, C. (2002). Identification with the Aggressor-An Interactive Tactic or an Intrapsychic Tomb?: Commentary on Paper by Jay Frankel. Psychoanalytic Dialogues 12, 153-158.

Derrida, J (1986). Forward: Fors: The Anglish Words of Nicholas Abraham and Maria Torok. The Wolf Man's Magic Word: A Cryptonymy. University of Minnesota.

Ferenczi, S. (1995). The Clinical Diary of Sandor Ferenczi. J. Dupont (Ed.), M. Balint and N. Zarday Jackson (Trans.). Harvard University Press.

Frankel, J. (2002). 'Exploring Ferenczi's Concept of Identification with the Aggressor: Its Role in Trauma, Everyday Life, and the Therapeutic Relationship. Psychoanalytic Dialogues, 12(1), 101-139.

Freud, S. (1991). Mourning and Melancholia. In A. Richards (Ed.), J. Strachey (trans.), Volume II, On Metapsychology (pp. 251-296). Penguin.

Ganteau, J.M. (2013). 'The Past won’t fit into Memory without Something Left Over'. In J.M. Ganteau and S. Onega (Eds.). Trauma and Romance in Contemporary British Literature (pp. 17-33). Routledge.

Gormley, S. (2009). Introduction. Working Papers on the Web. Retrieved from https://extra.shu.ac.uk/ wpw/chicklit/ gormley.html [Accessed 2019, October 14].

Honeyman, G. (2017). Eleanor Oliphant is Completely Fine. London: Harper Collins.

Knowles, J. (2004). Editorial. Diegesis: Journal of the Association for Research in Popular Fictions, 8 (Winter. pp. 3-4).

Leys, R. (2000). Trauma: A Genealogy. University of Chicago.

Montoro, R. (2012). Chick Lit: The Stylistics of Cappucino Fiction. Bloomsbury.

Rashkin, E. (1992). Family Secrets and the Psychoanalysis of Narrative. Princeton University Press.

Rashkin, E. (2008). Unspeakable Secrets and the Psychoanalysis of Culture. SUNY Press.

Santos Brigida, M. (2018). 'Oh, Look at All the Lonely People: Eleanor Oliphant is Completely Fine by Gail Honeyman Review'. Dardanina Revistelectronica 11(1). Retrieved from https://www.ufjf.br/darandina/ files/2018/08/Resenha-Marcela-Santos-Brigida.pdf [Accessed 2019, October 23].

Sprengnether, M. (2018). Mourning Freud. Bloomsbury.

Woods, J. (2018, May 15). Gail Honeyman: 'I hope Eleanor Oliphant has Helped to Fuel the Debate on Loneliness'. The Telegraph. Retrieved from https://www.telegraph.co.uk/women/life/gail-honeymanhope-eleanor-oliphant-has-helped-fuel-debate-loneliness/ [Accessed 2019, October 23].

Catherine MACMILLAN is an Associate Professor at the Department of English Language and Literature in Yeditepe University (Istanbul). She obtained her PhD (in European Studies) from Marmara University in 2008. Her research interests are interdisciplinary, including European Studies (with a focus on Turkey's relations with the EU, Brexit and populism) and literature (with a special interest in politics and literature). She published a monograph in 2014, Discourse, Identity and the Question of Turkish Accession to the EU: Through the Looking Glass, and edited another book, Contemporary Perspectives on Turkey's EU Accession Process, in 2018. She is also the author of various book chapters and articles. 